\title{
General Productivity Predicting Model for Skidder Working in Eucalypt Plantations
}

\author{
Mohammad Reza Ghaffariyan \\ Research Fellow, Australian Forest Operations Alliance (AFORA), Forest Industries Research Centre, \\ University of the Sunshine Coast, Maroochydore DC, Queensland, Australia
}

\begin{abstract}
Timber extraction from forest to the roadside/landing can be operated using cut-to-length, whole stem and whole tree. Skidding is one of the options for wood extraction. This paper aimed to review the available studies on work productivity of skidders in Eucalypt plantations. Reviewing the machine productivity information indicated that skidding productivity in Eucalypt plantations may be impacted by tree volume, load size, skid distance, slope of skid trail and power of the machine. Based on the reviewed literatures the machine productivity varied from 11.20 green tons per $\mathrm{PMH}_{0}$ (Caterpillar 528 operating in skidding distance of $251 \mathrm{~m}$ tested in USA) to 80.25 green tons per $\mathrm{PMH}_{0}$ (Timberjack 1710D operating in skidding distance of $241 \mathrm{~m}$ in Brazil). General productivity model was developed including variables such as skidding distance, tree size and power of machine. Future research could verify the impact of harvesting intensity/yield per ha, plantation layout (landing locations and block shape), operator experience, terrain conditions and availability of chippers/or processors at the landing in the case of hot decking on the productivity of the skidders in Eucalypt plantations.
\end{abstract}

Keywords: Harvesting, Skidding, Productivity, Tree volume, Load size, Skidding distance, Machine power

\section{Introduction}

Forest operations includes different components such as felling, bucking, extraction/yarding, loading, transportation, unloading and road construction (Conway, 1982). Extraction can be operated using cutto-length (wood assortments e.g. logs, pulpwood etc.), whole stem (without branches/tops) and whole tree.

Skidding is one of the most common methods for wood extraction (Uusitalo, 2010). Mechanical configurations of skidders include track/or wheel and grapple/or cable. Wheeled skidders are equipped with a small blade in the front to clear the skid trail and level small ground obstructions. Tracked skidders have a full dozer blade which can be used to construct landings and roads. A grapple skidder has a dedicated grapple to pick up more than one stem/log at a time. A cable skidder has a cable (and winch) with chokers that can be attached to logs/trees for skidding.

\section{Material and Methods}

\subsection{Machine Productivity for Skidders}

Discrimination of the effective factors in each stage and developing their corresponding time models helps forest managers to choose wisely the method of extracting wood, and efficiently manage the process of harvesting operations. One of the common ways to evaluate a harvesting system is time study and productivity evaluation (Ghaffariyan et al., 2012). Most of statistical models for predicting skidding time/or productivity indicate that skidding distance, piece size, load volume, winching distance (in the case of cable skidders) and slope of the skid trail impact on the productivity of skidding opreations (Sobhany and Stuart, 1991; Abeli, 1996; Daxner et al., 1997; Egan and Baumgras, 2003; Sabo and Porsinsky, 2005; Zecic et al., 2005). This study firstly aimed to review the available studies on skidding productivity in Eucalypt plantations. Secondly, the reviewed time studies were used to create a data base to develop a general productivity predicting model for skidders working in Eucalypt plantations.

\subsection{Overview of Skidding Productivity Studies in Eucalypt Plantations}

The literatures and information were obtained using following sources; collected time studies from Australian Forest Operations Research Alliance (AFORA) and online research papers published in English language academic journals by searching electronic databases including Google Scholar, Scopus, and Web of Science google. The keywords used in the searched included skidding, productivity, Eucalypt plantations, time study and grapple skidder. 
Two studies were conducted in California (USA) on fast-growing Eucalypt plantations. First study reported by Spinelli and Hartsough (2001) assessed the productivity of rubber-tired Caterpillar 528 grapple skidder to extract bunched whole trees to a landing in Eucalyptus plantation. The harvesting system included feller-buncher, grapple skidder and flail-chipper. In this study, a second skidder was applied to clear residues from around the flail-chipper and pilling them in specific area to be comminuted later. The terrain was flat, and the stand was 7 years old. The work cycle time was divided into travel empty, maneuver, grab, move and travel loaded. Skidding distance was significant variable impacting travel empty time while skidding distance and weight of load were significant factors influencing travel loaded time. Grab time was impacted by number of bunches per turn and load weight. Move time was only impacted by number of bunches per turn. The reported machine productivity details are presented in Table 1 . Second study in California was conducted in the same farm using same type of skidder as first study (Table 1). Spinelli et al. (2002) developed submodels for each element of skidding cycle. Travel empty time was a function of distance. Grab time was impacted by number of trees per bunches and load size. Move time depended on number of trees per bunches. Skidding distance and load size were significant variables affecting travel loaded time. Slope and terrain roughness did not significantly impact skidder working time.

Skidders are also applied for wood extraction in Brazil. Dos Santos et al. (2013) evaluated the time consumed by the elements of the work cycle, productivity, cost and operational efficiency of a Clambunk skidder in a eucalyptus stand in São Paulo
State, Brazil (Table 1). Trees were felled by fellerbuncher and extracted as whole-tree to road side to be chipped. Loading and travel loaded were more time consuming than travel loaded and unloading elements. The productivity was significantly influenced by the extraction distance. Authors of this study concluded that reduction in production cost could be possible by reorganizing the work process based on distance and other operational factors.

Australian plantation industry apply skidders within whole tree extraction operations. Several case studies have investigated productivity of skidders in Australia in the past years. In 2011, a trial was set up by Ghaffariyan et al. (2011) in a mixed Eucalyptus grandis hybrid (hybrid partner: E. camaldulensis) plantation located in Quindinup, Western Australia. Tree size was small thus producing export pulp chip was not considered profitable. The owner harvested the plantation for a biomass-pelletised product. The biomass material was produced from full-tree chipping including the stem, branches, leaves and bark. The harvesting system included a tracked feller-buncher, grapple skidder and mobile full-tree chipper. The feller-buncher felled trees and stacked them in bunches. The grapple skidder then moved the bunches to the chipper located at the roadside, near the block's edge. Whole trees were chipped and loaded directly to trailers to be transported to the pelletising plant. The elemental time study method (Björheden et al., 1995) was applied to record the time data of skidder. Skidding cycle time was divided into six elements: travel empty, loading, moving during loading, travel loaded to chipper, unloading and clearing the debris. Load weight and skidding distance were significant variables affecting machine productivity. Heavier loads increased the productivity while longer skidding distances reduced the productivity (Figure 1).

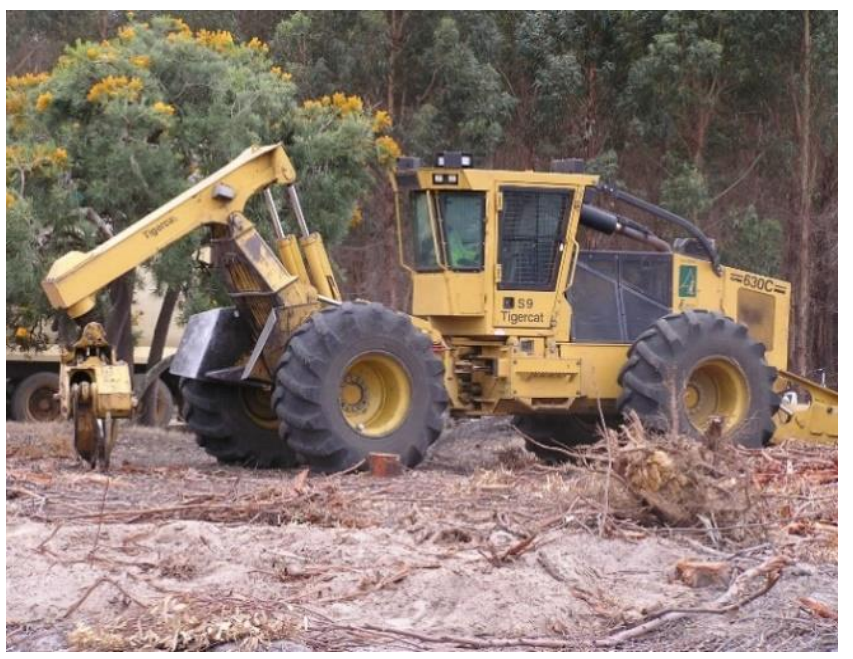

Figure 1. Tigercat 630C skidder operating within IFC-DDC in Western Australia

Another comprehensive trial was conducted in a Eucalyptus globulus plantation in south-west Western Australia (Ghaffariyan and Brown, 2013) where efficiency of four harvesting systems was compared.
These systems included cut-to-length (CTL), in-field chipping using a delimbing and debarking flail integrated with the chipper (IFC-DDC), in-field chipping using a chipper with a separate flail machine 
for delimbing and debarking (IFC-F/C) and whole tree to roadside (WTR) (Figure 2). Except CTL operation, trees were felled mechanically by a feller-buncher then skidded by grapple skidders to the road side for chipping or processing. The work elements were like earlier study mentioned (Ghaffariyan et al., 2011). Longer skidding distances reduced the skidder productivity. The productivity rates of three skidders studied within different harvest systems is included in Table 1.

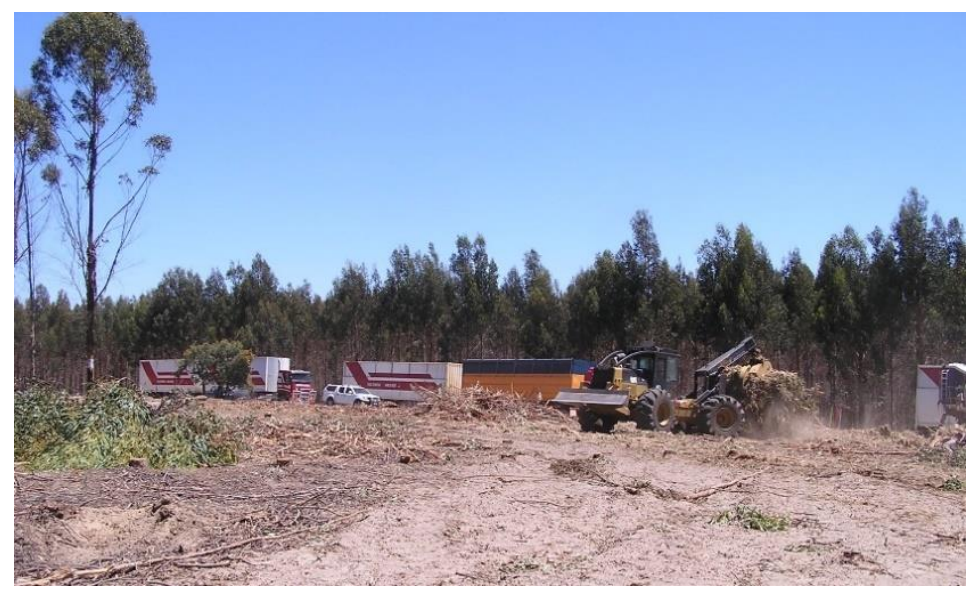

Figure 2. Caterpillar 545C skidder operating in within IFC-FC in Western Australia

Table 1. Summary of reported machine productivity of skidders operating in Eucalypt plantations (Note: $\mathrm{PMH}_{0}$ is productive machine hours. A factor of 1:1 was assumed to convert green tons to $\mathrm{m}^{3}$.)

\begin{tabular}{|c|c|c|c|c|c|c|c|c|}
\hline Machine model & $\begin{array}{c}\text { Power } \\
(k W)\end{array}$ & $\begin{array}{l}\text { Harvest } \\
\text { method }\end{array}$ & Species & $\begin{array}{c}\text { Tree } \\
\text { volume } \\
\left(\mathbf{m}^{3}\right)\end{array}$ & $\begin{array}{c}\text { Load } \\
\text { size } \\
\left(\mathbf{m}^{3}\right) \\
\end{array}$ & $\begin{array}{c}\text { Average } \\
\text { extraction } \\
\text { distance }(\mathbf{m})\end{array}$ & $\begin{array}{l}\text { Productivity } \\
\text { (green tons } \\
\text { per } \mathrm{PMH}_{0} \text { ) }\end{array}$ & Reference \\
\hline Caterpillar 528 & 130 & Whole tree & E. camaldulensis & 0.15 & 2.95 & 76 & 40.00 & $\begin{array}{l}\text { Spinelli and } \\
\text { Hartsough (2001) }\end{array}$ \\
\hline Caterpillar 528 & 130 & Whole tree & $\begin{array}{l}\text { E. camaldulensis } \\
\text { and E. viminalis }\end{array}$ & 0.19 & 0.56 & 251 & 11.20 & Spinelli et al., (2002) \\
\hline $\begin{array}{l}\text { Timberjack } \\
\text { 1710D }\end{array}$ & 160 & Whole tree & $\begin{array}{l}\text { E. urophylla X } E \text {. } \\
\text { grandis }\end{array}$ & 0.39 & NA & 241 & 80.25 & $\begin{array}{l}\text { Dos Santos et al., } \\
\text { (2013) }\end{array}$ \\
\hline Tigercat $630 \mathrm{C}$ & 186 & Whole tree & $\begin{array}{l}\text { E. grandis X E. } \\
\text { camaldulensis }\end{array}$ & 0.1 & 3.02 & 182 & 44.60 & $\begin{array}{l}\text { Ghaffariyan et al., } \\
\text { (2011) }\end{array}$ \\
\hline Tigercat 630D & 194 & $\begin{array}{l}\text { Whole tree } \\
\text { (IFC-F/C) }\end{array}$ & E. globulus & 0.18 & 4.58 & 246 & 31.45 & $\begin{array}{l}\text { Ghaffariyan and } \\
\text { Brown, (2013) }\end{array}$ \\
\hline $\begin{array}{l}\text { Caterpillar } \\
545 \mathrm{C}\end{array}$ & 173 & $\begin{array}{l}\text { Whole tree } \\
\text { (IFC-DDC) }\end{array}$ & E. globulus & 0.18 & 4.58 & 245 & 38.70 & $\begin{array}{l}\text { Ghaffariyan and } \\
\text { Brown, (2013) }\end{array}$ \\
\hline $\begin{array}{l}\text { Caterpillar } \\
545 \mathrm{C}\end{array}$ & 173 & $\begin{array}{l}\text { Whole tree } \\
\text { (log } \\
\text { processing) }\end{array}$ & E. globulus & 0.19 & 4.38 & 171 & 58.57 & $\begin{array}{l}\text { Ghaffariyan and } \\
\text { Brown, (2013) }\end{array}$ \\
\hline
\end{tabular}

\subsection{Model Development}

Productivity information (machine info, parameters and productivity record) were collected from literatures mentioned earlier (Table 1) and previous collected time studies by Australian Forest Operations Research Alliance (AFORA). Literatures in Table 1 yielded 7-times studies while AFORA's time studies (which have not been published) formed 21-time studies. The information of 28-time studies was used to set a data base in a statistical software SPSS IBM Statistics version 24. It was assumed that skidding productivity (green tons per $\mathrm{PMH}_{0}$ or $\mathrm{m}^{3} / \mathrm{PMH}_{0}$ ) was a function of machine power, tree volume $\left(\mathrm{m}^{3}\right)$, load size $\left(\mathrm{m}^{3}\right)$ and average skidding distance (m). Slope was constant in most of case studies as the operation occurred in flat terrain. Machine type was grapple skidder in the case studies considered in the statistical modelling. Regression analysis was used to evaluate the relationship between productivity and the independent variables.
Productivity predicting equation was developed using the multiple regression method with SPSS. The statistical procedure for modelling included the following steps: plotting cycle time against candidate predictors; collinearity testing; fitting the regression model; checking model consistency, fit and plausibility; analyzing the variance to test model significance; and examining the residuals.

The effect of each variable on skidding productivity was studied by changing one variable while holding the other variables constant at their mean value. The sensitivity results were graphed using a linear method for the independent variables.

\section{Results}

\subsection{General Skidding Productivity Predicting Model}

The regression method yielded following model in which skidding distance, tree volume and machine power were included as independent variables. 
Productivity (green tons $\left./ \mathrm{PMH}_{0}\right)=-41.138-0.082 \times$ Skidding distance $(m)+205.362 \times$ Tree volume $(\mathrm{m} 3)$ $+0.367 \times$ Machine power $(k W)$

$\mathrm{R}$-sq $=0.59$, Adjusted R-sq $=0.54$, number of observations $=28$. The analysis of variance (ANOVA) results confirmed that the developed model is significant at $\alpha=0.05$ (Table 2). Table 3 presents the collinearity statistics. The variance inflation factors for the coefficients of the model were very low, indicating there was minimal collinearity between the variables (Chatterjee and Price, 1991). The descriptive statistics of the parameters taken from the literatures and previous time studies on skidding is presented in Table 4.

Table 2. Analysis of variance for skidding productivity predicting model

\begin{tabular}{cccccc}
\hline & Sum of Squares & df & Mean Square & F & Sig. \\
\hline Regression & 10855.80 & 3 & 3618.60 & 11.11 & 0.00 \\
Residual & 7490.28 & 23 & 325.66 & & \\
Total & 18346.08 & 26 & & & \\
\hline
\end{tabular}

Table 3. Confidence intervals and collinearity statistics of the coefficient of the model.

\begin{tabular}{ccc}
\hline Model coefficients & Tolerance & Variance inflation factor (VIF) \\
\hline Power $(\mathrm{kW})$ & 0.84 & 1.19 \\
Tree volume $(\mathrm{m} 3)$ & 0.95 & 1.05 \\
Skidding distance $(\mathrm{m})$ & 0.86 & 1.17 \\
\hline
\end{tabular}

Table 4. Descriptive statistics of the parameters

\begin{tabular}{ccccc}
\hline & Minimum & Maximum & Mean & Std. Deviation \\
\hline Machine power $(\mathrm{kW})$ & 130.00 & 194.00 & 175.44 & 17.53 \\
Tree volume $\left(\mathrm{m}^{3}\right)$ & 0.10 & 0.48 & 0.23 & 0.09 \\
DBH $(\mathrm{cm})$ & 12.00 & 22.90 & 16.49 & 5.39 \\
Load size $\left(\mathrm{m}^{3}\right)$ & 0.56 & 12.00 & 4.09 & 2.59 \\
Skidding distance $(\mathrm{m})$ & 76.00 & 460.00 & 204.25 & 115.61 \\
\hline
\end{tabular}

To validate the developed regression model, a paired wise T-test was applied to compare the actual productivity data versus predicted productivity values by the model (Spinelli and Magagnotti, 2010). The Pvalue derived from the test was 0.68 which indicated that the model was valid at $\alpha=0.05$ as there was no significant difference between mean values of actual productivity and predicted ones.

\subsection{Sensitivity Analysis}

The impact of skidding distance, tree volume and machine power on productivity is illustrated in Figures 3, 4 and 5. Longer skidding distances can reduce the productivity due to increased travel times. According to Figure 3, an increase of $100 \mathrm{~m}$ in skidding distance can results in diminishing machine productivity up to $8.2 \mathrm{Gt} / \mathrm{PMH}_{0}$. If tree size increases to $0.1 \mathrm{~m}^{3}$ the machine productivity will increase about 20.5 $\mathrm{Gt} / \mathrm{PMH}_{0}$ (Figure 4). This is mainly due to the general rule of piece-size impact on harvesting machines efficiency that skidder may spend shorter time per each unit for larger tree sizes (loading and unloading time may reduce for larger piece size).

Figure 5 shows that the application of more powerful machine yields higher work productivity which is due to reduced work time and ability of carrying larger loads per turn. According to the model increasing machine power to $10 \mathrm{~kW}$ is equivalent to $3.7 \mathrm{Gt} / \mathrm{PMH}_{0}$ increase in skidder productivity. 


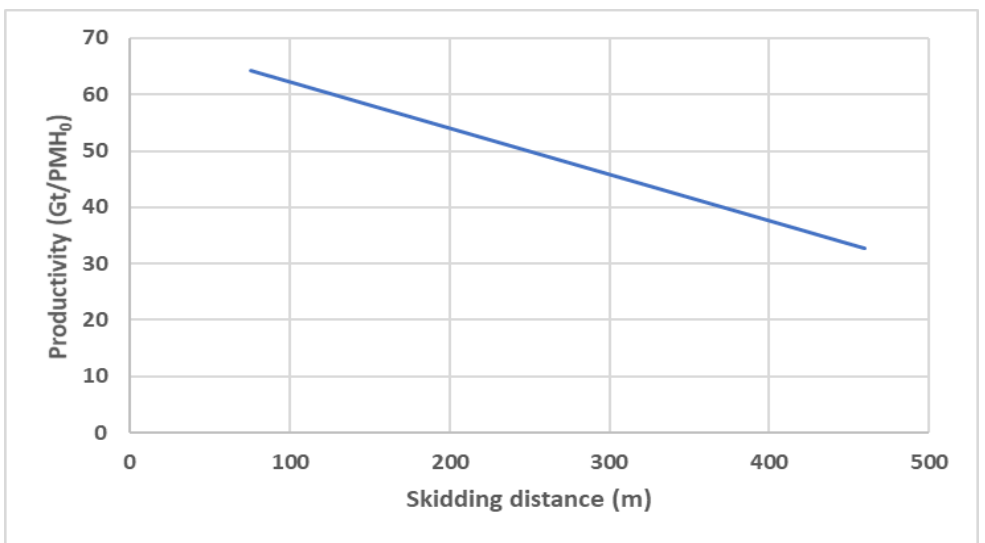

Figure 3. Impact of skidding distance on productivity

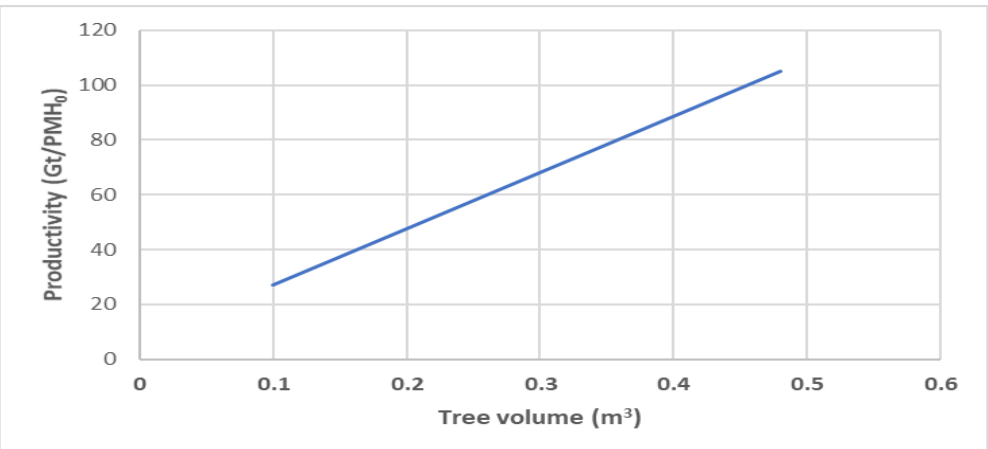

Figure 4. Impact of tree volume on productivity

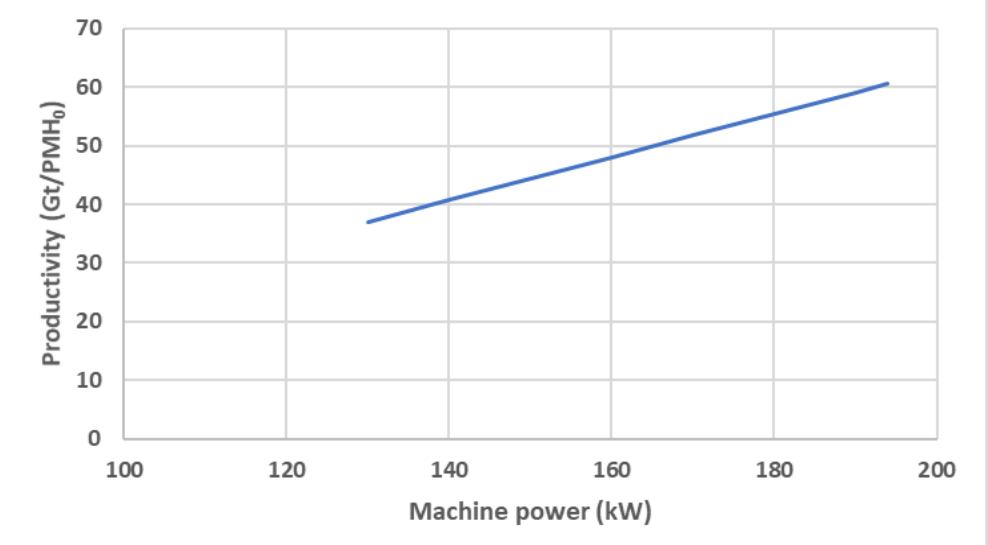

Figure 5. Impact of machine power on productivity

\section{Discussions}

Summarized productivity information presented in Table 1 indicates that skidding productivity in Eucalypt plantations varied from 11.20 green tons per $\mathrm{PMH}_{0}$ (Caterpillar 528 operating in skidding distance of $251 \mathrm{~m}$ tested in USA by Spinelli et al., 2002) to 80.25 green tons per $\mathrm{PMH}_{0}$ (Timberjack 1710D operating in skidding distance of $241 \mathrm{~m}$ in Brazil reported by Dos Santos et al., 2013). The difference between productivity might be explained by larger machine power and larger tree size $\left(0.39 \mathrm{~m}^{3}\right.$ compared with $0.19 \mathrm{~m}^{3}$ ).

When machine power/model were the same such as two case studies on Caterpillar 528 skidder (power of $130 \mathrm{~kW}$ ) in USA (Spinelli et al., 2002; Spinelli and Hartsough, 2001), smaller load size and longer skidding distances resulted in lower productivity
(11.20 green tons per $\mathrm{PMH}_{0}$ compared to 40 green tons per $\left.\mathrm{PMH}_{0}\right)$. In the case of two studies using Caterpillar $545 \mathrm{C}$ (power of $173 \mathrm{~kW}$ ) in Western Australia (Ghaffariyan and Brown, 2013) the lower productivity ( $38.70 \mathrm{~m} 3 / \mathrm{PMH} 0$ compared with $58.57 \mathrm{~m}^{3} / \mathrm{PMH} 0$ ) was mainly caused by longer skidding distance despite slightly higher load size and smaller tree size.

Applying powerful machines (Tigercat 630C with power of $186 \mathrm{~kW}$ (Ghaffariyan et al., 2011) and Tigercat 630D with the power of $194 \mathrm{~kW}$ (Ghaffariyan and Brown, 2013) did not necessarily result in higher productivity as the productivity can be influenced by other factors e.g. skidding distance, tree volume, load size, slope etc. In these two cases, long skidding distance and relatively small tree volume/load size might have prevented both powerful machines reaching high work productivity. 


\section{Conclusions}

Variables such as skidding distance, tree size and power of the machine were entered the general model for predicting productivity of grapple skidder (suitable for working conditions in Eucalypt plantations) as significant variables, which can be applied in harvesting planning by harvesting managers and contractors. Future research could verify the impact of harvesting intensity/yield per ha, plantation layout (landing locations and block shape), availability of chippers/or processors at the landing in the case of hot decking on skidding productivity in Eucalypt plantations. Operator experience can also influence machine productivity that can be studied. Terrain conditions (such as stump height, hazards, mound height) may impact the travel time of the skidders and may also cause damages to skidder operators which need to be investigated further. Next project could develop a skidding productivity predicting model for native Eucalypt plantations and coniferous plantations.

\section{Acknowledgement}

The author would like to thank to the reviewers of European Journal of Forest Engineering for providing useful suggestions on this paper.

\section{References}

Abeli, W. 1996. Comparing productivity and costs of three subgrading machines. International Journal of Forest Engineering, 5(1):33-39.

Björheden, R., Apel, K., Shiba, M., Thompson, M.A. 1995. IUFRO Forest work study nomenclature. Swedish University of Agricultural Science, Dept. of Operational Efficiency, Garpenberg. 16 pp.

Chatterjee, S., Price, B. 1991. Regression analysis by example. New York: John Wiley and Sons. Second edition. 278 p.

Conway, S. 1982. Logging practices: principles of timber harvesting systems. Miller Freeman Publications, San Francisco. 432p.

Daxner, P., Gutmann, A., Hager, H., Kroiher, F., Sagl, W., Stampfer, K., Sterba, H. 1997. Naturnahe Waldwirtschaft und deren Auswirkung auf das Oekosystem Wald. eine oekologische, waldwachstumkundliche, forsttechnische und soziooekonomische Studie, Universitaet fuer Bodenkultur,Vienna.
Dos Santos, P.H.A., De Souza, A.P., Marzano, F.L., Minette, L.J. 2013. Productivity and costs of eucalyptus wood extraction with clambunk skidder. Revista Arvore, Viçosa-MG, 37 (3): 511518.

Egan, A., Baumgras, G.E. 2003. Ground skidding and harvested stands attributes in Appalachian hardwood stands in West Virginia. Forest Product Journal, 53(9):59-63.

Ghaffariyan, M.R., Brown, M., Acuna, M., Sessions, J., Kuehmaier, M., Wiedemann, J. 2011. Biomass harvesting in Eucalyptus plantations in Western Australia. Southern Forests, 73(3\&4): 149-154.

Ghaffariyan, M.R., Naghdi, R., Ghajar, I., Nikooy, M. 2012. Time prediction models and cost evaluation of Cut-To-Length (CTL) harvesting method in a mountainous forest. Small-scale Forestry, 12:181192.

Ghaffariyan, M.R., Brown. M. 2013. Selecting the efficient harvesting method using multiple criteria analysis: A case study in south-west Western Australia. Journal of Forest Science (Czech), 59 (12): 479-486.

Sabo. A., Porsinsky, T. 2005. Skidding of fir round wood by timberjack 240c. Croatian Journal of Forest Engineering, 26(1):13-27.

Spinelli, R., Hartsough, B.R. 2001. Extracting whole short rotation trees with a skidder and a front- end loader. Biomass and Bioenergy, 2011: 425-431.

Spinelli, R., Hartsough, B.R., Owende, P.M.O., Ward, S.M. 2002. Productivity and cost of mechanized whole-tree harvesting of fast-growing Eucalypt stands. International Journal of Forest Engineering, 13(2): 49-60.

Spinelli, R., Magagnotti, N. 2010. A tool for productivity and cost forecasting of decentralised wood chipping. Forest Policy and Economics, 12: 194-198.

Sobhany, H., Stuart, W.B. 1991. Harvesting systems evaluation in Caspian Forests. International Journal of Forest Engineering, 2(2): 21-24.

Uusitalo, J. 2010. Introduction to forest operations and technology. JVP Forest Systems Oy. Hameenliana. $287 \mathrm{p}$.

Zecic, Z., Krpan, A.B.P., Vukusic, S. 2005. Productivity of C Holder $870 \mathrm{~F}$ tractor with double drum winch Igland 4002 in thinning beech stands. Croatian Journal of Forest Engineering, 26(2): 49-57. 